\title{
Analysis of Woody Plants Dimensions on the Affected and Restricted Land Management Practices in Sudan Vegetation Zone, Adamawa State, Nigeria
}

\author{
${ }^{* 1}$ GANDAPA, EN; ${ }^{2}$ MATAPA, JI \\ ${ }^{1}$ Department of Geography, Nigerian Defence Academy, Kaduna, P.M.B. 2109, Kaduna, \\ Kaduna State, Nigeria. \\ *Corresponding Author Email: edwingandapa@yahoo.com; Tel. +2348032989727 \\ ${ }^{2}$ Department of Geography, Nigerian Army University Biu, P.M.B.1500, Biu, Borno State, Nigeria \\ Email: jacksonmatapa@gmail.com; Phone No.+2347035241719
}

\begin{abstract}
Human activities have transformed the vegetal environment into affected and restricted areas with varied woodland dimensions. The aim of the study is to identify the difference in distributions, heights, girths and bole lengths of native woody plants on continuous cultivation, fallow and reserve lands of Hong Local Government Area in 2018. Data on woody plants distributions, heights, girths and bole lengths were generated from the field using quadrat samples and measuring tape. Stratified sampling technique was adopted to cover the study area while purposively sampling method was adopted to establish the sample quadrats on the three dissimilar land management practices adopted. Variance was used to analyze the data while ' $F$ ' distribution at $0.05 \%$ confidence limit was used to test for the significance. From the result, there are 181 woody plant stands observed on the 12 sample plots $\left(1800 \mathrm{~m}^{2}\right)$. The woodland distributions vary from 17,13 and 1 on fallow, reserve and continuous cultivation lands on $100 \mathrm{~m}^{2}$. The tallest $(11.37 \mathrm{~m})$ woodlands are on continuous cultivation land followed by the reserve $(10.20 \mathrm{~m})$ while the shortest $(2.58 \mathrm{~m})$ is on fallow land. The girths vary from $1.89 \mathrm{~m}, 1.03 \mathrm{~m}$ and $0.23 \mathrm{~m}$ on continuous cultivation, reserve and fallow lands respectively. The stems are $4.34 \mathrm{~m}$, $2.53 \mathrm{~m}$ and $0.80 \mathrm{~m}$ for reserve, continuous cultivation and fallow lands. For significant increase in tree distributions farmers should preserve seedlings during annual clearing and clean weeding as well adopt longer fallow period. The result implies with increase in human activities such as arable farming and wood harvesting lead to decrease in plant distribution and vice versa.
\end{abstract}

DOI: https://dx.doi.org/10.4314/jasem.v24i1.24

Copyright: Copyright (C) 2020 Umukoro et al. This is an open access article distributed under the Creative Commons Attribution License (CCL), which permits unrestricted use, distribution, and reproduction in any medium, provided the original work is properly cited.

Dates: Received: 30 November 2019; Revised: 20 December 2019; Accepted: 23 December 2019

Keywords: Land management practices, Native woodlands, Savanna region, woodland dimensions

Environment provides resources and sits for human survival. Therefore, components of the environment have never remained static in form, but changes do occur that led to concern over disappearing of vegetation cover (Environmental Agency, 2007). Increase in human population manifested by competitive landuse causes land scarcity, conversion of wild lands to agricultural and built-up areas in the local environment (Kanianska, 2016).

Landuse practices such as arable farming is one of the major causes of changes in woodland distribution. The over use of the reserve lands for arable farming especially the expansion of fragmented farmlands in many parts of sub-Sahara Africa under the demographic pressure have led to devegetation (Neba, 2009). Shifting cultivation is the major system of arable farming practiced by peasant communities in Asia, Africa and Latin America since the Neolithic period $(13,000$ to $3,000 \mathrm{BC})$ which affects woodlands adversely due to forward and backward clearance (Karthic et al., 2009).
Result of study indicate that the adoption of slash-andburn, rotational bush fallow, continuous cultivation and clean weeding as management techniques for exotic plants causes reduction in species diversity, crowdedness, regeneration, and sizes of native plants on the affected areas (Freeman et al., 2014; Mazzott et al., 2013; Jamala et al., 2012). Pantami et al., (2010) maintained that bush fires depending on severity, temperature and frequency deplete vegetation cover through destruction of susceptible stands, reduce the height and girth of woody plants by burning the apical meristem and bark. Studies revealed that sunlight, temperature, soil fertility and moisture determine sizes of woody plants (British Trust for Ornithology, 2019; Field Study Council, 2009).

Results of studies on importance of woody plants dimensions like bole length, girth, height and distribution are important by protecting the Earth's surface from erosion and soil desiccation (Zang, 2016; Houser, 2012; Lutz et al., 2012). Therefore, estimation 
of woody plants distribution, girth and height is essential in monitoring tree quality, and management of vegetation cover (Mweresa et al., 2017).

Results of studies especially those of Mazzotti et al., (2013); Freeman et al., (2014) are important by observing that vegetation cover is degrading due to increase in human activities such as arable farming, wood harvesting and bush burning. However, these studies did not significantly carry out micro-scale study on the Sudan vegetation characterized by sparse woodland covers neither embarked on assessment of woody plant characteristics that are affected adversely by arable farming nor restricted their studies to comparative analysis of indigenous woody plants distributions, heights, girths and bole length on the affected and restricted land management practices adapted in Hong Local Government Area, Adamawa State, Nigeria.

In Hong Local Government Area, exotic species such as guinea corn, groundnuts, beans and maize are important by providing food materials and commodity of trade. However, the continuous and substantial cultivation of these crops significantly affects indigenous woody plants distributions, heights, girths and bole lengths unfavorably. Furthermore, result of field observation revealed that farmlands on fallow and continuous cultivation contrast significantly from reserve land in woodlands dimensions.

It is from the above perspectives the study was embarked upon to identify the distributions, heights, girths and bole lengths of indigenous woodlands on continuous cultivation, fallow and reserve land management practices. The objectives include: to identify the land management practices adapted in the study area; to determine distributions, heights, girths and bole lengths of indigenous woody plants; and to highlight the possible causes of difference in woodland dimensions in the area.

The scope covers Hong Local Government Area of Adamawa State, Nigeria. The focus is to identify indigenous woody plants distributions, heights, girths and bole lengths on farmlands under continuous cultivation, fallow and reserve lands in 2018 with a view to highlight the difference. The study is significant by identifying woodlands dimensions on the adopted land management practices. Monitoring dimensions of native woody plants community enable researchers and policy makers to precisely understand the impacts of arable farming on woodland degradation (Ansari et al., 2016). The study is restricted to native woodlands because they form the fundamental environmental resource base of the area that is observably degrading. The study excludes exotic species of woodlands because they are managed and form insignificant part of the environmental resource base of the populace. Woody plant within this study applies to trees, shrubs and herbs that have hard material beneath their bark which is the main supporting tissues (Beaulieu, 2019).

Geographic Background to the Study Area: Hong Local Government Area lies approximately between latitudes $09^{0} 57^{\prime} 26.079^{\prime \prime}$ to $10^{0} 34^{\prime} 7.517^{\prime \prime} \mathrm{N}$ and between longitudes $12^{0} 29^{\prime} 54.298^{\prime \prime}$ to $13^{0} 06^{\prime} 30.705^{\prime \prime} \mathrm{E}$ (Nigeria: Administrative Division, 2016). It is located in Adamawa State, Nigeria. It has an approximate landmass of $2,486 \mathrm{~km}^{2}$. The mean annual rainfall varies between 700 to $1000 \mathrm{~mm}$. The dry season is usually experienced from the months of November to April of the following year while the wet season is from May to October every year. The mean daily temperature is between $36^{\circ}$ to $41^{\circ} \mathrm{C}$ of the dry season to about $20^{\circ}$ to $25^{\circ} \mathrm{C}$ during the wet season (Online Nigeria, 2017). The low rainfall and high temperature implies that increase in woodland dimension is restricted to the rainy season when moisture is available to plants. Relief and landform of the area is generally undulating with highlands ranging from about $426 \mathrm{~m}$ to $1158 \mathrm{~m}$ above mean sea level (Garkida, Nigeria, Sheet 155). Because of the hilly and hard soils woodlands are short and sparsely distributed. The vegetation lies within the Sudan zone characterized by short and scattered woody plants (Makinwa, 2018). The vegetal resources harvested include fuelwood, poles, haft, charcoal, herbs, native vegetables and fruits. The population increased from 112,845 in 1976 to 175,564 in 2018 (National Population Commission, 2010). Thus, population density increased from 45 to 71 persons per $\mathrm{km}^{2}$ while land per capita decreased from 22.22 to $14.08 \mathrm{~m}^{2}$. The decrease in land per capita affects vegetation cover adversely due to pressure on available land for arable farming and settlement. Arable farming is the most important economic activity in the area. The people practice mono cropping, continuous cultivation, crop rotation and rotational bush fallow on crops such as Arachis hypogaea, Sorghum vulgare, Phaseolus coccineus and Zea mays while orchard gardens on Mangefera indica, Psidium guayava, Phoenix sylvestris and Eucalyptus camaldulensis are managed on small scale.

\section{MATERIALS AND METHODS}

Types of data required for the study include distributions, heights, girths and bole lengths of native woodlands. The metric for distribution is total number of stands on sample quadrat of $100 \mathrm{~m}^{2}$ (Purcell et al., 2016). Data on distributions, heights, girths and bole lengths are compared to determine the magnitude of 
difference in dimension between woodlands on affected and restricted land management practices. Data on distributions, heights, girths and bole lengths were generated from the field by direct measurements. Instruments used to generate the data are measuring tape to determine height, girth, bole length of woodland stand and size of the sample quadrats; and plastic netting (nylon) ropes to construct the sample quadrats.

Sample quadrats were adopted to demarcate the study plots within which distributions, heights, girths and bole lengths of woody plant were detected (Minnesota Project, 2012). Vodopich (2010) observed that a sample square quadrat is the most widely used method to demarcate study plots within which to measure numbers of woody plants in a terrestrial community. The uniform size $\left(100 \mathrm{~m}^{2}\right)$ and shape (square) of the sample quadrats were adopted because the plots are ideal for observing woody plant stands in Sudan vegetation zone characterized by sparse woody plant, but small enough to count all indigenous woodlands in a reasonable time.

The height of each standing woody plant was determined from the ground level at the base to the highest apical meristem, the girth at the base while the bole length from the ground surface to the first branching point of the trunk. Furthermore, a clinometer was used to determine the height of woody plants (American Forest Measuring Guidelines, 2013; Offwell Woodland and Wildlife Trust, 2010; Private Native Forestry Code of Practice Guideline, 2007). However, where because of the clinometer's limitation to generate data on a single tree height on the reserve land due inadequate bare space to view the apex and distance (base line) between the observer to the base of the tree, supplementary method using measuring tape; and a pole considerably long, thin, straight and strong were adopted (Gandapa, 2015). The process includes: first, by climbing the tall tree up to a convenient bole to come closer to the apex; second, the pole on which a measuring tape was nailed at the tip was directed to the person at the bole that raised the pole to reach the remaining height of the tree; third, the height of the tree was determined on the ground surface at the base in metres (Gandapa, 2015). To cover the study area stratified sampling technique was adopted. The area $\left(2486 \mathrm{~km}^{2}\right)$ was divided into six (6) sections that served as a guide to locate the twelve (12) sample quadrats as shown on Figure I. From each sub section, farmland on continuous cultivation, fallow and reserve lands were identified. On each one (1) sample quadrat was established purposively to avoid bare lands devoid of woodland stand. Woodland heights, girths and bole lengths of all stands were measured while the crowdedness was recorded.

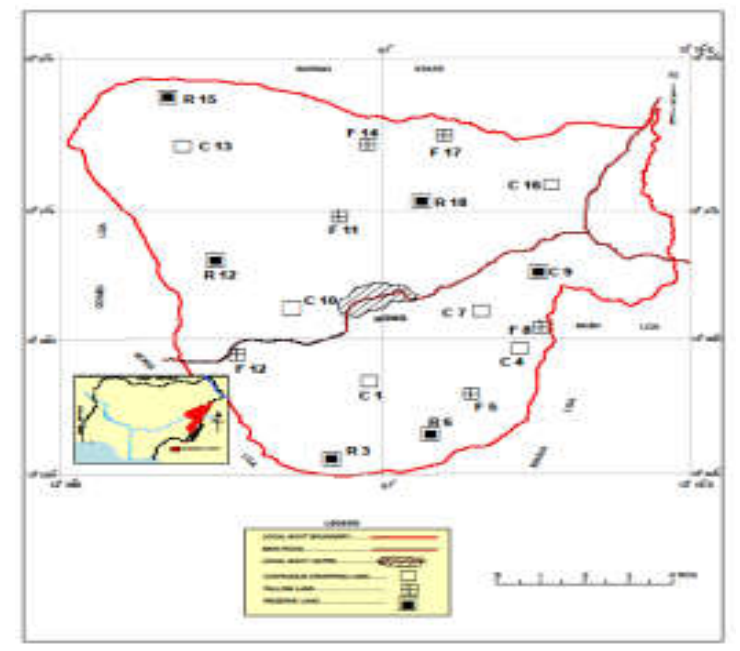

Fig. I: Sample Quadrats Location

Generated data on woodland distributions, heights, girths and bole lengths on the three (3) land management practices were analyzed by comparison to highlight the magnitude of differences. Likewise, variance was adopted to determine the magnitude of difference between the three (3) sects of woodland numbers generated on continuous cultivation, fallow and reserve land management practices. This is to test the assumption that there exist significant differences in woodland distributions on continuous cultivation, fallow and reserve lands. ' $F$ ' distribution at $0.05 \%$ confidence limit was used to test for the significance.

\section{RESULTS AND DISCUSSION}

There are 181 woody plant stands observed on the 18 sample quadrats $\left(1800 \mathrm{~m}^{2}\right)$. The distributions varied from 99, 79 and 3 on fallow, reserve and continuous cultivation lands respectively. Fallow and reserve lands are less varied (17 and 13) on $100 \mathrm{~m}^{2}$ than the continuous cultivation land with 1 (one). There is insignificant difference in height between those on continuous cultivation $(11.37 \mathrm{~m})$ and reserve lands $(10.20 \mathrm{~m})$ than fallow land $(2.58 \mathrm{~m})$. Likewise plants on continuous cultivation and reserve lands are more uniform in girth $(1.89$ and $1.03 \mathrm{~m})$ than fallow land $(0.23 \mathrm{~m})$. There is significant dissimilarity in bole length between plants on reserve, continuous cultivation and fallow lands with $4.34 \mathrm{~m}, 2.53 \mathrm{~m}$ and $0.80 \mathrm{~m}$ accordingly.

For emphasis the results on identified variations in woodland distributions, heights, girths and bole lengths are discussed below. Table 1 present summary of woody plants distributions, girths, heights and bole lengths on continuous cultivation, fallow and reserve lands. Distributions of Woody Plants: From the result, 
the magnitude of distributions of woodland stands on the three varied land management practices compared differ from $54.70 \%, 43.64 \%$ and $1.66 \%$ on fallow, reserve and continuous cultivation lands respectively.

Table 1: Woody Plants Dimensions on Adapted Land Management Practices

\begin{tabular}{|c|c|c|c|c|c|}
\hline $\begin{array}{l}\text { Land Mgt. } \\
\text { Practices }\end{array}$ & $\begin{array}{l}\text { Quadrat } \\
\text { No. }\end{array}$ & $\begin{array}{l}\text { Distribution } \\
\left(100 \mathrm{~m}^{2}\right)\end{array}$ & $\begin{array}{l}\text { Girth } \\
\text { (m) }\end{array}$ & $\begin{array}{l}\text { Height } \\
\text { (m) }\end{array}$ & $\begin{array}{l}\text { Bole Length } \\
\text { (m) }\end{array}$ \\
\hline \multirow{8}{*}{ 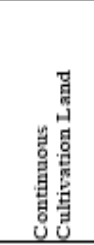 } & 1 & 1 & 2.10 & 9.30 & 3.20 \\
\hline & 4 & - & - & - & - \\
\hline & 7 & - & - & - & - \\
\hline & 10 & 1 & 1.98 & 11.80 & 3.10 \\
\hline & 13 & - & - & - & $\cdot$ \\
\hline & 16 & 1 & 1.59 & 13.00 & 1.30 \\
\hline & Total & 3 & 5.67 & 34.10 & 7.60 \\
\hline & Average & $0.5(1)$ & 1.89 & 11.37 & 2.53 \\
\hline \multirow{8}{*}{ 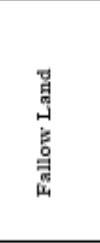 } & 2 & 12 & 0.17 & 2.61 & 0.81 \\
\hline & 5 & 18 & 0.29 & 2.66 & 0.82 \\
\hline & 8 & 21 & 0.18 & 2.39 & 0.86 \\
\hline & 11 & 27 & 0.23 & 3.04 & 1.15 \\
\hline & 14 & 15 & 0.25 & 2.38 & 0.75 \\
\hline & 17 & 6 & 0.25 & 2.38 & 0.41 \\
\hline & Total & 99 & 1.37 & 15.46 & 4.80 \\
\hline & Average & 17 & 0.23 & 2.58 & 0.80 \\
\hline \multirow{8}{*}{ 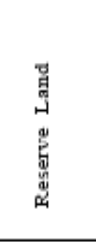 } & 3 & 6 & 1.63 & 13.75 & 4.96 \\
\hline & 6 & 12 & 1.30 & 11.16 & 5.10 \\
\hline & 9 & 12 & 0.57 & 7.78 & 4.97 \\
\hline & 12 & 30 & 0.36 & 10.60 & 3.20 \\
\hline & 15 & 18 & 0.49 & 9.80 & 5.67 \\
\hline & 18 & 1 & 1.81 & 8.13 & 2.12 \\
\hline & Total & 79 & 6.16 & 61.22 & 26.02 \\
\hline & Average & 13 & 1.03 & 10.20 & 4.34 \\
\hline
\end{tabular}

Source: Field Study, 2018.

From Table 1, the average distributions on $100 \mathrm{~m}^{2}$ shows 17, 13 and 1 on fallow, reserve and continuous cultivation lands accordingly. The reason for the occurrence of highest (17) distribution of woodlands on fallow lands could be attributed to loose soil structure due to cultivation that took place before abandoned that favour regeneration of seedlings, and lack of significantly matured tree stands that could smother the seedlings. Likewise, the higher (13) distribution on the reserve land may be due to occurrence of significantly matured tree stands that are better adapted to the environment and deny new invading species from survival because of their inability to compete positively for sunlight, space and air. Furthermore, there could be selective harvesting of certain species. The least (1) distribution occur on farmlands under continuous cultivation. This is because of the repeated annual clearing and clean weeding, and mechanical plowing that uproot seedlings and cut off lateral roots of trees. Moreover, some of the preserved species like Cordia abyssinica and Acacia nilotica later dry up due to excessive harvesting of the bark and roots for medicinal purpose. The result implies fallow and reserve land management practices should be adopted to conserve tree distributions because they retain more woody plant stands.
Comparing the results of the computed ' $\mathrm{F}$ ' value ($2.45)$ to the Table ' $F$ ' value $(2.48)$ at $0.05 \%$ confidence limit the result falls within the accepted region. The assumption that there is a significant difference between the distributions of woody plants among continuous cropping, reserve and fallow lands is not statistically accepted. Fallow and reserve lands are less varied (17 and 13) and more uniform in woody plant distributions than the continuous cropping land all still in 1 (one) on $100 \mathrm{~m}^{2}$. The insignificant difference (4) in woody plant distributions on fallow and reserve lands could be due to wood harvesting for poles, hafts and fuelwood from matured trees on the reserve, and environmental factors such as rock types. Likewise, the significant difference (16) between fallow and continuous cropping lands is due to annual clearing and clean weeding at the detriment of distributions on continuous cropping lands. The result implies with decrease in arable farming and wood harvesting leads to increase in woody plant distributions and vice versa.

Height of Woody Plants: From Table 1, the height of woodlands in the area varied from 11.37, 10.20 and $2.58 \mathrm{~m}$ on continuous cultivation, reserve and fallow lands respectively. The reason for the occurrence of tallest $(11.37 \mathrm{~m})$ woodlands on land under continuous cultivation could be attributed to their location on area devoid of bush fires which aid their growth in height. The woodlands on the reserve lands are equally tall $(10.20 \mathrm{~m})$ due to crowdedness with average of 13 stands on $100 \mathrm{~m}^{2}$. Therefore, the density encourages competitive growth in height to access the sunlight while the shortness $(7.78 \mathrm{~m})$ revealed by some stands is attributed to inadequate access to sunlight, air and space induced by the taller $(10.20 \mathrm{~m})$ stands. Furthermore, woodlands on fallow lands form the shortest $(2.58 \mathrm{~m})$ category because they are not stable and newly invaded the abandoned farmland that is exhausted in soil nutrients required by plants. From the results, the average height of woodlands in the area varies from less than 2.38 to about $13.007 \mathrm{~m}$.

Girth of Woody Plants: Results on woody plants girth revealed $1.89 \mathrm{~m}, 1.03 \mathrm{~m}$ and $0.23 \mathrm{~m}$ on continuous cultivation, reserve and fallow lands accordingly as shown on Table 1. The reasons for the occurrence of the broadest $(1.89 \mathrm{~m})$ girth of trees on continuous cultivation land than those on fallow $(0.23 \mathrm{~m})$ and reserve lands $(1.03 \mathrm{~m})$ remains they are not affected by the adverse effects of occasional bush fire which dehydrate tissues and burn the bark; they have additional sources of nutrients from the fertilizer and manure that are applied to crops such as groundnuts and guinea corn; and they are sparsely distributed with a single stand on $100 \mathrm{~m}^{2}$ as shown on Table 1 . These conditions aid their growth in thickness more than 
woody plants on the reserve (13) and fallow (17) lands that are crowded with inadequate space for growth in thickness. The girth of woody plants on reserve lands indicates $1.03 \mathrm{~m}$ as shown on Table 1 . Because of the closeness (13 stands on $100 \mathrm{~m}^{2}$ ) there is inadequate nutrient and space for growth in thickness, and their bark could be burnt by occasional bush fires. Likewise, woody plants on the fallow land have the narrowest girth $(0.23 \mathrm{~m})$. This is attributed to the highest distributions of 17 stands on $100 \mathrm{~m}^{2}$ as shown on Table 1. The high density imply inadequate space for growth in thickness; the secondary woodlands are not left for a period of about 50years to develop into full-grown woodlands, but are cleared for backward rotational arable farming; and the woodlands are new arrivals to the abandoned infertile farmlands.

Bole Length of Woody Plants: The length of trunk from the ground surface to the first branch of the woodlands varies from one land management practice to another. From Table 1, the distribution of stem length varied from $4.34 \mathrm{~m}, 2.53 \mathrm{~m}$ and $0.80 \mathrm{~m}$ for reserve, continuous cultivation and fallow lands respectively. The explanations for the occurrence of the longest trunk in woodlands on reserve land could be the trees are matured, they are stable by least affected by human activity like massive removal than secondary woodlands on fallow lands, and they are crowded (13 stands on $100 \mathrm{~m}^{2}$ ). The crowdedness possibly caused degeneration of weaker branches due to smothering, and to conserve moisture and nutrients for the branches that are more buoyant. Nonetheless, preserved woody plants on the continuous cultivation lands have shorter $(2.53 \mathrm{~m})$ bole than the reserve $(4.34 \mathrm{~m})$. For the reasons they are well spaced (1 stand on $100 \mathrm{~m}^{2}$ ), and are not affected by bush fires. These conditions favour tillering at a short length from the ground surface. The preserved woody plants because of adequate space develop numerous branches with broad canopy cover to protect their roots from direct heat of the sun and to conserve soil moisture within immediate surroundings of the roots. More importantly, secondary woodlands on fallow lands have the shortest stem $(0.80 \mathrm{~m})$ because they are immature and are new arrivals to the disturbed areas. Therefore, they are undergoing vegetative growth in height and thickness which are associated with numerous tillers. To this end, the result of this study is in line with those of Mozzotti et al., (2013); Neba (2009); Environmental Agency (2007) that characteristics of vegetation cover is bound to change due to human activities such as arable farming and wood harvesting that significantly reduce indigenous woody plant sizes.
Conclusion: From the results, human activities such as massive removal of woody plants for arable farming, and adoption of shorter fallow periods by the farmers cause variations in woodland distributions, girths, heights and bole lengths. This implies with increase in human activities such as arable farming and wood harvesting leads to decrease in woody plants dimensions and vice versa. The result indicates there is no significant difference in woodland dimensions on the three land management practices compared. Based on the results of this study, the following recommendations are made: Arable farmers should preserve seedlings of woodlands during annual clearing and clean weeding to increase distributions. More importantly, longer fallow period should be adopted by farmers to enable the secondary woodlands attain maturity with advantage on increase in height, girth and bole length. Further research should be conducted to come up with substantial reasons that cause difference in heights, girths and bole lengths of preserved woody plants on continuous cultivation lands from those on the reserve lands. Likewise, public enlightenment should be conducted by environmentalists on the effects of insignificant woody plants distributions, heights and girths on the environment.

Acknowledgements: I am grateful to Mrs. Dorcas I. Bello, Mr. Gilbert E. Nyako, Mr. Joshua E. Nyako, Mr. Fanny F. Nyako, Mr. Josiah E. Nyako and Mr. Joel E. Nyako for their contributions during data collection and analysis.

\section{REFERENCE}

American Forest Measuring Guidelines (2013). Tree Height Measurements. Retrieved from https://en.wikipedia.

org/wiki/Tree_measurement

Ansari, A; Gill, SS; Abbas, ZK; Naeem, M (eds) (2016). Plant Biodiversity. Retrieved from http://www.

cabi.org/bookshop/book/9781780646947
Beaulieu, D (2019). Woody Plants: Meaning, Examples. Retrieved from https://www.thespruce.com/woody- plants-meaning-examples-2131128

British Trust for Ornithology (2007). Influence of Climate Change on the Abundance, Distribution and

Phenology of Woodland Bird Species in Temperate Regions. Retrieved from https://onlinelibrary.wiley. com/doi/epdf/10.1111/j.1474-919X.2007.00729.x 
Environmental Agency (2007). Farming and Habitat. Retrieved from http://agriculturepro.blogspot.com/

Field Studies Council 2009. Woodland plants. Retrieved from https://www.field-studiescouncil.org.urbaneco/ urbaneco/woodland/shading.htm

Freeman, ED; Sharp, TR; Larsen, RT; Knight, RN; Slater, SJ; Mc Milan, BR (2014). Negative Effects of an Exotic Grass Invasion on Small Mammal Communities. Retrieved from http://journals.plos.org

Gandapa, EN (2015). "Supplementary Methods Adapted to Determine Standing Woody Plants Height and Biomass in Ph. D. Geography Research". Journal of Environmental and Earth Science. International Institute of Science, Technology and Education. 5(8) 22-25

Garkida, Nigeria, Sheet 155

Houser, S (2012). The Importance of Low Branching Limbs. Retrieved from https://www.arborilogical.com/

articles/all-articles/articlerespository/2012/august/the-importance-of-lowbranching-limbs/

Jamala, GY; Boni, PG; Abraham, P; Teru, CP (2012). Evaluation of Environmental Impact of Bush Burning in Southern Guinea Savanna of Adamawa State, Nigeria. American Journal of Experimental Agriculture, 2(3) 359-369. Retrieved from http://int.search. $\% 5$ EY6 $\% 5$ Expv $185 \% 5$ ETTAB02\%5Eng\&ptb=2 5B2A743-B984-4F9C84B1388F744BDAC $8 \& n=7849 \mathrm{c} 580 \& \mathrm{cn}=\mathrm{NG} \& 1$ $\mathrm{n}=\mathrm{en} \& \mathrm{si}=$

Kanianska, R (2016). Agriculture and Its Impact on Land-Use, Environment, and Ecosystem Services. Retrieved

from https://www.intechopen.com/books/landscapeecology-the-influences-of-land-use-andanthropogenic-impacts-of-landscapecreation/agriculture-and-its-impact-

Karthic, T; Veeraswami, GG; Samal, PK (2009). Forest Recovery Following Shifting Cultivation: An Overview of Existing Research. Tropical Conservation Science 2(4); 374-387
Lutz, JA; Larson, AJA; Swanson, ME; Freund, JA (2012). Ecological Importance of Large-Diameter Trees in a Temperate Mixed-Conifer Forest. Retrieved from https://journals.plos.org/plosone/article?id= 10.1371/journal.pone.0036131

Makinwa, E (2018). Vegetation Zones in Nigeria and their Features. Retrieved from https://www.legit.ng/

1096264-vegetation-zones-nigeria-features.html

Mazzotti, FJ; Center, TD; Dray, FA; Thayer, D (2013). Ecological Consequences of Invasion by Melaleuca quinquenervia in South Florida Wetlands: Paradise Damaged not lost. Retrieved from

http://int.search.myway.com/search/GGmain.jht $\mathrm{ml} ? \mathrm{n}=7849 \mathrm{c} 580 \& \mathrm{p} 2=\% 5 \mathrm{EY} 6 \% 5 \mathrm{Expv} 185 \% 5 \mathrm{ET}$ ТАВ $02 \%$

Minnesota Project (2012). Ecological Sampling Methods. Retrieved from http://int.search.myway.com/search/

GGmain.jhtml?p2=\%5EY6\%5Expv185\%5ETT

AB02\%5Eng\&ptb=25B2A743-B984-

4F9C84B1388F744BDAC8\&n=7849c580\&cn=

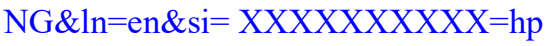

Mweresa, IA; Odera, PA; Kuria, DN; Kenduiywo, BK (2017). Estimation of Tree Distribution and

Canopy Heights in Ifakara, Tanzania Using Unmanned Aerial System (UAS) Stereo Imagery. American Journal of Geographic Information System 6(5) 187-200

National Population Commission (2010). 2006 Population and Housing Census. Priority Table Vol. iv. Pp. 13, 14

Neba, NE (2009). Cropping System and Post Cultivation Vegetation Successions: AgroEcosystems in Ndop, Cameroun. Journal of Human Ecology 27(1) 27-33

Nigeria: Administrative Division (2016). States and Local Government Areas. Available: https://www.

citypopulation.de/php/nigeria-admin.php (Accessed 12 December, 2019)

Offwell Woodland and Wildlife Trust (2010). Teachers Notes: How to Find the Height of a Tree. Retrieved from http://www.google.com.ng 
Online Nigeria (2017). Climate of Nigeria. Retrieved from

http://www.onlinenigeria.com/links/adv.asp?blur $\mathrm{b}=70$

Pantami, SA, Voncir, N; Babaji, GA, Mustapha, S (2010). Effects of Burning on Soil Chemical Properties in the Dry Sub-Humid Savanna Zone of Nigeria. Retrieved from http://int.search.myway.com/search/GGmain.

jhtml? $\mathrm{n}=7849 \mathrm{c} 580 \& \mathrm{p} 2=\% 5 \mathrm{EY} 6 \% 5 \mathrm{Expv} 185 \% 5 \mathrm{ETT}$ AB02\%5Eng\&ptb=25B2A743-B984-4F9C84B1388F744BDAC $8 \& q \mathrm{~s}=\& \mathrm{si}=$

Private Native Forestry Code of Practice Guideline (2007). Techniques for Measuring Stand Height. Retrieved from

http://int.search.myway.com/search/GGmain.jhtml?p $2=\% 5$ EY6\%5Expv185\%5ETTAB02\%5Eng\&ptb
25B2A743-B984-4F9C-84B1-

Purcell, KL; Verner, J; Drynan, DA; Mori, SR; Olsen, RG; Wible, VP (2016). Ecosystem Processes.

Retrieved from https://www.fs.fed.us/psw/topics/ecosystem_pro cesses/ sierra/bio_diversity/habitat_relationship_terrestri al_sub5/abundance

Vodopich, DS (2010). Ecology Laboratory Manual. New York, Mc Graw Hill publisher, p. 92

Zang, RG (ed) (2016). Tree Circumference Dynamics in Four Forests Characterized Using Automated

Dendrometer Bands. Retrieved from https://www.ncbi.nlm.nih.gov/pmc/articles/PMC 5193451/ 